\title{
Knowledge of HPV, HPV-induced cancers, and HPV vaccine among university students in medical laboratory science disciplines: Nigerian study
}

\author{
Kehinde Kazeem Kanmodi' ${ }^{1}$ Obi Chidiebere², Njideka Jacob Nwafor'1, Babatunde Abiodun Amoo' \\ ${ }^{1}$ Cephas Health Research Initiative Inc., Ibadan, Nigeria \\ ${ }^{2}$ Department of Microbiology, Federal University, Birnin Kebbi, Nigeria
}

\begin{abstract}
Introduction: Human papillomavirus (HPV) is a leading cause of notorious diseases affecting humans. Students in medical laboratory science disciplines are a population group at high risk of being infected with HPV.

Aim: To assess the knowledge of HPV, HPV-induced cancers, and HPV vaccine among university students in laboratory science disciplines, studying at the Federal University, Birnin Kebbi, Nigeria.

Material and methods: A cross-sectional survey of 150 students in laboratory science disciplines at the Federal University, Birnin Kebbi was conducted using a self-administered questionnaire obtaining information on their socio-demographic characteristics and knowledge of HPV, HPV-induced cancers, and HPV vaccine. Collected data was analysed using SPSS version 20 software.

Results: The majority (52.7\%) of the respondents were females. Only $45.3 \%$ of them had ever heard of HPV, of whom $26.5 \%(n=68)$ found out about it from internet sources. No significant relationship $(p>0.05)$ exists between the socio-demographic attributes of the respondents and their awareness of HPV, except for their course of study $(p=0.009)$. Furthermore, an in-depth assessment of knowledge of these respondents $(n=68)$ shows that they have huge knowledge gaps on HPV, HPV-induced cancers, and HPV vaccine. Furthermore, there exists statistically significant associations between gender of respondents and their knowledge of: "transmissibility of HPV through sexual intercourse", "magnitude of risk of having multiple sexual partners", "extent of protection offered by HPV vaccination", and "clearance of HPV infections" $(p<0.05)$.

Conclusions: There is a need for school-based education programs targeted at educating students on the prevention strategies that are needed to be HPV free.

Key words: human papillomavirus, vaccine, cancer, medical, students, knowledge, Nigeria,
\end{abstract}

Corresponding author: Dr. Kehinde Kazeem Kanmodi, Cephas Health Research Initiative Inc., Nigeria, phone: +2347032329156 , e-mail: kanmodikehinde@yahoo.com 


\section{Introduction}

Human papillomavirus (HPV) infection continues to be the leading cause of notorious diseases affecting humans: HPV-induced cervical cancer (CC), HPV-induced head and neck cancer (HNC), genital warts, etc. [1-6]. Amongst these diseases, the most devastating of all are CC and HNC [1-6]. These HPV-induced cancers are highly notorious, affecting the mucosal lining of the cervix (CC) and upper aero-digestive tract (HNC) [1-6].

Globally, about 510,000 women are newly diagnosed with invasive HPV-induced CC every year [7]. Also, about 30,000 men and women are newly diagnosed with HPV-induced HNC yearly [8]. Over 100 serotypes of HPV exist, including types $6,11,16,18,31,33,35$, and $39[1,9]$. However, not all HPV types are responsible for HPV-induced cancers; the types that causes HPV-induced cancers are called oncogenic HPVs, and they include types 16 and $18[3,4]$.

HPV transmission routes from person to person have been well documented in scientific literature, and they include: sexual intercourse (e.g. oral sex, anal sex, and vaginal sex), skin-to-skin contact, and parturition [10-14]. The prevalence of lifetime risk of HPV infection is as high as $80 \%$ [15]. Based on the aforementioned, it can be asserted that almost everybody will be infected with HPV infection at some point in their lifetime.

Despite the high virulence of HPV [1-15], it is unfortunate that many people in Nigeria are not aware of the virus. To make it worse, the vaccine that can prevent people from getting HPV-induced diseases is yet to be introduced into the Nigerian routine immunisation schedule, unlike in other developed countries like the USA, Australia, and Germany [16-18]. Without mincing words, the best way suggested to prevent HPV-induced diseases in Nigeria, due to the problem of nonexistence of HPV vaccination in Nigeria's routine immunisation program, is to educate the public about HPV and its risk factors.

After a view into the virulence and risk factors of HPV, the authors found that university students in laboratory science disciplines are at high risk of getting infected by HPV. This conclusion was arrived at based on logical reasoning: 1) these students are adults and they are of childbearing age; hence, some of them may be sexually active; 2) they often come into contact with bio specimens, some of which may be infected with HPV. Hence, it will be of significance to conduct a scientific study to assess their knowledge of HPV, $\mathrm{HPV}$-induced cancers, and HPV vaccine. However, after an extensive literature search on HPV-related studies conducted in Nigeria, it was found that there is a paucity of literature on HPV knowledge among this high-risk group.

\section{Aim}

Hence, this study was conducted with the aim of assessing the knowledge of HPV, HPV-induced cancers, and HPV vaccine among university students in laboratory science disciplines, studying at the Federal University, Birnin Kebbi - a new university in Nigeria.

\section{Material and methods}

This study was a descriptive cross-sectional study conducted among students of Microbiology and Biochemistry degree programs at the Federal University, Birnin Kebbi, Kebbi State, Nigeria. Permission to conduct this survey was obtained from the Heads of the surveyed departments. The study tool was a questionnaire obtained from a similar study on HPV awareness conducted among Nigerian monotechnic freshmen [19].

A total of 273 and 257 students (from $1^{\text {st }}$ year to final $\left(4^{\text {th }}\right)$ year) were enrolled in the Departments of Microbiology and Biochemistry, respectively, during the time of data collection (i.e. December 2018 to January 2019). Out of a total of 530 students eligible for the study, a sample of 150 students was used as the minimum sample size for the study; the sample size was determined based on the authors' convenience.

Table I. Socio-demographic variables of the respondents

\begin{tabular}{|c|c|c|}
\hline Variables & Frequency $(N=150)$ & Percentage \\
\hline \multicolumn{3}{|l|}{ Gender: } \\
\hline Male & 71 & 47.3 \\
\hline Female & 79 & 52.7 \\
\hline \multicolumn{3}{|l|}{ Age [years]: } \\
\hline $15-19$ & 25 & 16.7 \\
\hline $20-24$ & 99 & 66.0 \\
\hline $25-29$ & 21 & 14.0 \\
\hline 30 and above & 5 & 3.3 \\
\hline \multicolumn{3}{|l|}{ Level of study: } \\
\hline $1^{\text {st }}$ year & 40 & 26.7 \\
\hline $2^{\text {nd }}$ year & 3 & 2.0 \\
\hline $3^{\text {rd }}$ year & 31 & 20.7 \\
\hline $4^{\text {th }}$ year & 76 & 50.7 \\
\hline \multicolumn{3}{|l|}{ Ethnicity: } \\
\hline Yoruba & 21 & 14.0 \\
\hline Hausa & 99 & 66.0 \\
\hline Igbo & 6 & 4.0 \\
\hline Others & 24 & 16.0 \\
\hline \multicolumn{3}{|l|}{ Religion: } \\
\hline Christianity & 26 & 17.3 \\
\hline Islam & 123 & 82.0 \\
\hline Traditional & 1 & 0.7 \\
\hline \multicolumn{3}{|l|}{ Course of study: } \\
\hline Biochemistry & 32 & 21.3 \\
\hline Microbiology & 118 & 78.7 \\
\hline \multicolumn{3}{|c|}{ Family background: } \\
\hline Monogamous & 87 & 58.0 \\
\hline Polygamous & 57 & 38.0 \\
\hline Polyandry & 1 & 0.7 \\
\hline Single parent & 5 & 3.3 \\
\hline
\end{tabular}


Table II. Awareness and sources of information on HPV

\begin{tabular}{|c|c|c|}
\hline Variable & Frequency & Percentage \\
\hline \multicolumn{3}{|c|}{ Heard of HPV? $(n=150)$ : } \\
\hline Yes & 68 & 45.3 \\
\hline No & 82 & 54.7 \\
\hline \multicolumn{3}{|c|}{ Source of information on $\mathrm{HPV}^{*}(n=68)$ : } \\
\hline Friends & 6 & 8.8 \\
\hline Parents & 1 & 1.5 \\
\hline TV/radio & 15 & 22.1 \\
\hline Internet & 18 & 26.5 \\
\hline Doctor/nurse & 7 & 10.3 \\
\hline Clinic/hospital & 12 & 17.7 \\
\hline Others & 24 & 35.3 \\
\hline
\end{tabular}

These students were visited in their classrooms, they were informed about the aims and objectives of the study; they were also informed that their participation in the study was strictly voluntary. Only those $(n=157)$ who were willing to participate in the study were issued a self-administered questionnaire after giving verbal informed consent.

\section{Statistical analysis}

All issued questionnaires were returned to the investigators. During the data cleaning process, seven questionnaires were discarded because they were not completely/appropriately filled. Hence, we used the data of 150 participants for the study. Data were computed using the SPSS version 20 software for analysis. The frequency distributions of all variables were determined; tests of associations between relevant variables were also done, using the $\chi^{2}$ test. A $p$-value $<0.05$ was used as the yardstick to determine the level of statistical

Table III. Association between socio-demographic characteristics of respondents and awareness of HPV

\begin{tabular}{|c|c|c|c|c|}
\hline Variable & $\begin{array}{c}\text { Aware of HPV } \\
n(\%)\end{array}$ & $\begin{array}{c}\text { Not aware of HPV } \\
n(\%)\end{array}$ & Chi-square value $\left(\chi^{2}\right)$ & $P$-value \\
\hline Gender: & & & 0.355 & 0.551 \\
\hline Male & $34(47.9)$ & $37(52.1)$ & & \\
\hline Female & $34(43.0)$ & $45(57.0)$ & & \\
\hline Age [years]: & & & 1.385 & 0.709 \\
\hline $15-19$ & $9(36.0)$ & $16(64.0)$ & & \\
\hline $20-24$ & $48(48.5)$ & $51(51.5)$ & & \\
\hline $25-29$ & $9(42.9)$ & $12(57.1)$ & & \\
\hline 30 and above & $2(40.0)$ & $3(60.0)$ & & \\
\hline Level of study: & & & 16.764 & 0.001 \\
\hline 100 & $13(32.5)$ & $27(67.5)$ & & \\
\hline 200 & $2(66.7)$ & $1(33.3)$ & & \\
\hline 300 & $7(22.6)$ & $24(77.4)$ & & \\
\hline 400 & $46(60.5)$ & $30(39.5)$ & & \\
\hline Ethnicity: & & & 3.974 & 0.264 \\
\hline Yoruba & $8(38.1)$ & $13(61.9)$ & & \\
\hline Hausa & $44(44.4)$ & $55(55.6)$ & & \\
\hline Igbo & $5(83.3)$ & $1(16.7)$ & & \\
\hline Others & $11(45.8)$ & $13(54.2)$ & & \\
\hline Religion: & & & 1.077 & 0.584 \\
\hline Christianity & $13(50.0)$ & $13(50.0)$ & & \\
\hline Islam & $55(44.7)$ & $68(55.3)$ & & \\
\hline Traditional & $0(0.0)$ & $1(100.0)$ & & \\
\hline Course of study: & & & 6.786 & 0.009 \\
\hline Biochemistry & $8(25.0)$ & $24(75.0)$ & & \\
\hline Microbiology & $60(50.8)$ & $58(49.2)$ & & \\
\hline Family background: & & & 0.991 & 0.803 \\
\hline Monogamous & $39(44.80$ & $48(55.2)$ & & \\
\hline Polygamous & $27(47.4)$ & $30(52.6)$ & & \\
\hline Polyandry & $0(0.0)$ & $1(100.0)$ & & \\
\hline Single parent & $2(40.0)$ & $3(60.0)$ & & \\
\hline
\end{tabular}


significance in the $\chi^{2}$ test. Results generated were presented as descriptions and as tables.

\section{Results}

More than half $(66 \%)$ of the respondents were within the age range of 20-24 years; their gender distribution was fairly even: $52.7 \%$ were females. Roughly half $(50.7 \%)$ were in their $4^{\text {th }}$ year of study, $66.0 \%$ were Hausas, $82.0 \%$ were Muslims, $78.7 \%$ were in a Microbiology discipline, and $58.0 \%$ had monogamous family background (Table I).

Among the entire 150 respondents that were included in this study, only $45.3 \%$ of them had ever heard of HPV, of whom $26.5 \%(n=68)$ found out about it from internet sources (Table II). Bivariate analysis showed no significant relationship $(p>0.05)$ between the cross-tabulated so-

Table IV. Assessment of knowledge of respondents on HPV and HPV vaccine

\begin{tabular}{|c|c|c|c|c|}
\hline Items & $\begin{array}{c}\text { True }(n=68) \\
n(\%)\end{array}$ & $\begin{array}{c}\text { False }(n=68) \\
n(\%)\end{array}$ & $\begin{array}{c}\text { Not sure }(n=68) \\
n(\%)\end{array}$ & Correct answer [Ref.] \\
\hline Men cannot develop HPV Infection & $10(14.7)$ & $25(36.8)$ & $33(48.5)$ & False [8] \\
\hline HPV is very rare & $26(38.2)$ & $6(8.8)$ & $36(52.9)$ & False $[7,8,15]$ \\
\hline There are many types of HPV & $29(42.6)$ & $7(10.3)$ & $32(47.1)$ & True $[1,9]$ \\
\hline HPV can be found in the mouth & $17(25.0)$ & $9(13.2)$ & $42(61.8)$ & True [8] \\
\hline HPV can cause HIV/AIDS & $12(17.6)$ & $17(25.0)$ & $39(57.4)$ & False [20] \\
\hline $\begin{array}{l}\text { HPV can be transmitted through } \\
\text { sexual intercourse }\end{array}$ & $32(47.1)$ & $6(8.8)$ & $30(44.1)$ & True [10] \\
\hline HPV can be passed on during oral sex & $28(41.2)$ & $6(8.8)$ & $34(50.0)$ & True $[8,10]$ \\
\hline $\begin{array}{l}\text { Persons infected with HPV usually } \\
\text { has symptoms }\end{array}$ & $37(54.4)$ & $4(5.9)$ & $27(39.7)$ & False [1] \\
\hline $\begin{array}{l}\text { Chances of getting HPV increases } \\
\text { with number of sexual partners }\end{array}$ & $26(38.2)$ & $7(10.3)$ & $35(51.5)$ & True $[8,10,11]$ \\
\hline $\begin{array}{l}\text { Most types of HPV cannot clear up on } \\
\text { their own }\end{array}$ & $21(30.9)$ & $8(11.8)$ & $39(57.3)$ & False [15] \\
\hline HPV can be cured by antibiotics & $24(35.3)$ & $11(16.2)$ & $33(48.5)$ & False $[1,5,14,20]$ \\
\hline $\begin{array}{l}\text { Most sexually active persons will get } \\
\text { HPV at some point }\end{array}$ & $19(27.9)$ & $10(14.7)$ & $39(57.4)$ & True $[8,10,11,15]$ \\
\hline $\begin{array}{l}\text { Having sex at an early age increases } \\
\text { risk of getting HPV }\end{array}$ & $17(25.0)$ & $13(19.1)$ & $38(55.9)$ & True $[8,10,11,15,21]$ \\
\hline HPV causes cervical cancer & $34(50.0)$ & $2(2.9)$ & $32(47.1)$ & True [7] \\
\hline HPV causes head and neck cancer & $14(20.6)$ & $9(13.2)$ & $45(66.2)$ & True [8] \\
\hline HPV is the same as HIV & $3(4.4)$ & $39(57.4)$ & $26(38.2)$ & False [20] \\
\hline $\begin{array}{l}\text { HPV test can tell how long you have } \\
\text { been infected with HPV }\end{array}$ & $14(20.6)$ & $13(19.1)$ & $41(60.3)$ & True $[23,24]$ \\
\hline $\begin{array}{l}\text { If a person tests positive for HPV, he/ } \\
\text { she will definitely get HNC }\end{array}$ & $7(10.3)$ & $14(20.6)$ & $47(69.1)$ & False $[1,3,4,9]$ \\
\hline $\begin{array}{l}\text { There is an HPV vaccine that can } \\
\text { prevent cancer in men and women }\end{array}$ & $23(33.8)$ & $7(10.3)$ & $38(55.9)$ & True [7] \\
\hline HPV vaccine requires 3 doses & $11(16.2)$ & $4(5.9)$ & $53(77.9)$ & True [22] \\
\hline $\begin{array}{l}\text { HPV vaccine offers protection against } \\
\text { all STls }\end{array}$ & $16(23.5)$ & $12(17.6)$ & $40(58.8)$ & False [7] \\
\hline $\begin{array}{l}\text { HPV vaccine is most effective for } \\
\text { those who have never had sex }\end{array}$ & $8(11.8)$ & $12(17.6)$ & $48(70.6)$ & True [1] \\
\hline $\begin{array}{l}\text { Someone who has had HPV vaccine } \\
\text { cannot get HNC }\end{array}$ & $6(8.8)$ & $13(19.1)$ & $49(72.1)$ & False [1] \\
\hline $\begin{array}{l}\text { Recommended age for getting HPV } \\
\text { vaccine is } 11 \text { to } 26 \text { years }\end{array}$ & $11(16.2)$ & $9(13.2)$ & $48(70.6)$ & True [1] \\
\hline
\end{tabular}

[Ref.] - Reference. 
cio-demographic attributes of the respondents and their awareness of HPV, except for their course of study ( $p=$ 0.009) (Table III).

An assessment of the knowledge of those respondents $(n=68)$ that were aware of HPV shows that they have huge knowledge gaps on HPV, HPV-induced cancers, and HPV vaccine (Table IV) [20-24]. For instance, only one-quarter (25.0\%) of them knew that HPV can be found in the mouth, while less than half (47.1\%) knew that HPV can be transmitted through sexual intercourse. Furthermore, there exists statistically significant associations between the gender of respondents and their knowledge of: "transmissibility of HPV through sexual intercourse", "magnitude of risk of having multiple sexual partners", "extent of protection offered by HPV vaccination", and "clearance of HPV infections" ( $p$ $<0.05)$ (Table V).

Table V. Associations between gender and knowledge of HPV, HPV-induced cancers, and HPV vaccine

\begin{tabular}{|c|c|c|c|}
\hline \multirow[t]{2}{*}{ Items } & \multicolumn{2}{|c|}{ Correct answers, grouped by gender } & \multirow[t]{2}{*}{$P$-value } \\
\hline & $\begin{array}{c}\text { Male }(n=34) \\
n(\%)\end{array}$ & $\begin{array}{c}\text { Female }(n=34) \\
\quad n(\%)\end{array}$ & \\
\hline Men cannot develop HPV Infection & $16(47.1)$ & $9(26.5)$ & 0.090 \\
\hline $\mathrm{HPV}$ is very rare & $4(11.8)$ & $2(5.9)$ & 0.590 \\
\hline There are many types of HPV & $13(38.2)$ & $16(47.1)$ & 0.450 \\
\hline HPV can be found in the mouth & $5(14.7)$ & $12(35.3)$ & 0.146 \\
\hline HPV can cause HIV/AIDS & $12(35.3)$ & $5(14.7)$ & 0.108 \\
\hline $\begin{array}{l}\text { HPV can be transmitted through sexual } \\
\text { intercourse }\end{array}$ & $11(32.4)$ & $21(61.8)$ & 0.030 \\
\hline HPV can be passed on during oral sex & $10(29.4)$ & $17(50.0)$ & 0.200 \\
\hline $\begin{array}{l}\text { Persons infected with HPV usually has } \\
\text { symptoms }\end{array}$ & $2(5.9)$ & $2(5.9)$ & 0.208 \\
\hline $\begin{array}{l}\text { Chances of getting HPV increases with number } \\
\text { of sexual partners }\end{array}$ & $8(23.5)$ & $18(52.9)$ & 0.017 \\
\hline Most types of HPV cannot clear up on their own & $6(17.6)$ & $2(5.9)$ & 0.039 \\
\hline HPV can be cured by antibiotics & $6(17.6)$ & $4(14.7)$ & 0.597 \\
\hline $\begin{array}{l}\text { Most sexually active persons will get HPV at } \\
\text { some point }\end{array}$ & $9(26.5)$ & $10(29.4)$ & 0.390 \\
\hline $\begin{array}{l}\text { Having sex at an early age increases risk of } \\
\text { getting HPV }\end{array}$ & $5(14.7)$ & $12(35.3)$ & 0.036 \\
\hline HPV causes cervical cancer & $16(47.1)$ & $18(52.9)$ & 0.270 \\
\hline HPV causes head and neck cancer & $7(20.6)$ & $7(20.6)$ & 0.936 \\
\hline HPV is the same as HIV & $21(61.8)$ & $18(52.9)$ & 0.698 \\
\hline $\begin{array}{l}\text { HPV test can tell how long you have been } \\
\text { infected with HPV }\end{array}$ & $5(14.7)$ & $9(26.5)$ & 0.401 \\
\hline $\begin{array}{l}\text { If a person tests positive for HPV He will } \\
\text { definitely get HNC }\end{array}$ & $5(14.7)$ & $9(26.5)$ & 0.478 \\
\hline $\begin{array}{l}\text { There is an HPV vaccine that can prevent cancer } \\
\text { in men and women }\end{array}$ & $10(29.4)$ & $13(38.2)$ & 0.131 \\
\hline HPV vaccine requires 3 doses & $4(11.8)$ & $7(20.6)$ & 0.610 \\
\hline HPV vaccine offers protection against all STIs & $11(32.1)$ & $1(2.9)$ & 0.001 \\
\hline $\begin{array}{l}\text { HPV vaccine is most effective for those who } \\
\text { have never had sex }\end{array}$ & $2(5.9)$ & $6(17.6)$ & 0.079 \\
\hline $\begin{array}{l}\text { Someone who has had HPV vaccine cannot get } \\
\text { HNC }\end{array}$ & $7(20.6)$ & $6(17.6)$ & 0.952 \\
\hline $\begin{array}{l}\text { Recommended age for getting HPV vaccine is } \\
11 \text { to } 26 \text { years }\end{array}$ & $4(11.8)$ & $7(20.6)$ & 0.403 \\
\hline
\end{tabular}




\section{Discussion}

The problem of HPV-induced cancers Nigeria is huge [25]. Unfortunately, lay public awareness of the virus, its risk factors, and its associated diseases is generally low in Nigeria [26]. The general low awareness rate among the lay public may be due to the weak efforts on public education on HPV in Nigeria. However, health professionals and trainees are supposed to be at least aware of HPV, its risk factors, and associated diseases, even if they lack in-depth knowledgeable about HPV. In this study, we surveyed university students in medical laboratory science disciplines on their knowledge of HPV. We found that the majority of them had never heard of HPV at all. By comparing the awareness rate recorded in this present study with that reported in other literature, we found that the awareness rate recorded in this study is higher than that reported in a similar study conducted among Nigerian freshmen in health science disciplines [19].

Also, it was observed that internet and TV/radio were the two most utilised specific sources of our respondents' information on HPV. However, this finding contradicts what was reported in a Nigerian study conducted by Kanmodi et al. [19], where media and health practitioners were the top two sources of information on HPV among their respondents. This shows that there are diverse sources of information on HPV among Nigerian students in health disciplines.

It is also noteworthy that there were some erroneous conceptions among our respondents as regards information pertaining to HPV infection, HPV risk factors, HPV-induced cancers, and HPV vaccines, because many of them had incorrect knowledge about vital information on these themes. For instance, not many of our respondents actually knew that HPV can be transmitted through sexual intercourse. However, by putting gender distribution into play, our data analysis showed that the surveyed females were found to be generally more knowledgeable than males on issues pertaining to HPV transmission, HPV risk factors, HPV-induced cancers, and HPV vaccines. This finding is similar to that reported in a similar Nigerian study [19].

By taking a look at the peculiarities of our study population, it can be said that is very important to educate them on HPV because they are high-risk groups. Pertinently, if students in medical disciplines could demonstrate a knowledge gap as huge as that reported in this study, then it can be concluded that students in non-medical academic disciplines will demonstrate more knowledge deficits on the surveyed themes. However, there are many benefits associated with educating university students on HPV disease prevention; a major benefit is that they will be able to educate others on HPV and also take all necessary precautions against getting infected with the disease.

However, this study has its limitations. First, this study was a single-centre study, and it only surveyed students in medical laboratory science disciplines; hence, it will be difficult to make unguided generalisations based on the study data.

\section{Conclusions}

This study shows that there is a need for school-based education programs targeted at public education on the risks of HPV infection and as well the prevention strategies that are needed to be HPV free.

\section{Conflict of interest}

The authors declare no conflict of interest.

\section{References}

1. Braaten KP, Laufer MR. Human papillomavirus (HPV), HPV-related disease, and the HPV vaccine. Rev Obstet Gynecol 2008; 1: 2-10.

2. Bosch FX, Lorincz A, Muñoz N, et al. The causal relation between human papillomavirus and cervical cancer. J Clin Pathol 2002; 55: 244-65.

3. Münger K, Howley PM. Human papillomavirus immortalization and transformation functions. Virus Res 2002; 89: 213-28.

4. Husain N, Neyaz A. Human papillomavirus associated head and neck squamous cell carcinoma: Controversies and new concepts. J Oral Biol Craniofac Res 2017; 7: 198-205.

5. Westra WH. The morphologic profile of HPV-related head and neck squamous carcinoma: implications for diagnosis, prognosis, and clinical management. Head Neck Pathol 2012; 6 (Suppl 1): S48-54.

6. Bishop JA, Westra WH. Human papillomavirus-related small cell carcinoma of the oropharynx. Am J Surg Pathol 2011; 35: 1679-84.

7. World Health Organization (WHO) Initiative for Vaccine Research. Human papilloma infection and cervical cancer. Vol 4. Geneva, Switzerland: WHO; 2008. [Accessed January 30, 2008]. http://www.who.int/vaccine_research/diseases/hpv/en/

8. Kreimer AR, Alberg AJ, Daniel R, et al. Oral human papillomavirus infection in adults is associated with sexual behavior and HIV serostatus. J Infect Dis 2004; 189: 686-98.

9. Muñoz N, Bosch FX, de Sanjosé S, et al. Epidemiologic classification of human papillomavirus types associated with cervical cancer. N Engl J Med 2003; 348: 518-27.

10. Kjaer SK, Chackerian B, van den Brule AJ, et al. High-risk human papillomavirus is sexually transmitted: evidence from a follow-up study of virgins starting sexual activity (intercourse). Cancer Epidemiol Biomarkers Prev 2001; 10: 101-6.

11. Winer RL, Lee SK, Hughes JP, Adam DE, Kiviat NB, Koutsky LA. Genital human papillomavirus infection: incidence and risk factors in a cohort of female university students. Am J Epidemiol 2003; 157: 218-26.

12. Kashima H, Leventhal B, Mounts P; Papilloma Study Group. Scoring system to assess severity and course in recurrent respiratory papillomatosis. In: Papillomaviruses: Molecular and clinical aspects. Howley PM, Broker TR (eds.). Alan R. Liss, New York, NY 1985; 125-35.

13. Fredericks BD, Balkin A, Daniel HW, Schonrock J, Ward B, Frazer IH. Transmission of human papillomaviruses from mother to child. Aust N Z J Obstet Gynaecol 1993; 33: 30-2.

14. Austen DF, Reynolds P, Schottenfeld D, Fraumeni JF. Laryngeal Cancer. Oxford University Press Inc, New York 1996.

15. Rodríguez AC, Schiffman M, Herrero R, et al.; Proyecto Epidemiològico Guanacaste Group. Rapid clearance of human papilloma- 
virus and implications for clinical focus on persistent infections. J Natl Cancer Inst 2008; 100: 513-7.

16. Patel C, Brotherton JML, Pillsbury A, et al. The impact of 10 years of human papillomavirus (HPV) vaccination in Australia: what additional disease burden will a nonavalent vaccine prevent? Euro Surveill 2018; 23: 1700737.

17. Lekoane KMB, Kuupiel D, Mashamba-Thompson TP, Ginindza TG. Evidence on the prevalence, incidence, mortality and trends of human papilloma virus-associated cancers in sub-Saharan Africa: systematic scoping review. BMC Cancer 2019; 19: 563.

18. Vuyst HD, Alemany L, Lacey C, et al. The burden of human papillomavirus infections and related diseases in Sub-Saharan Africa. Vaccine 2013; 31: F32-46.

19. Kanmodi KK, Ogbeide ME, Fagbule OF, et al. Knowledge of HPV, HPV-induced cancers, and HPV vaccine among a sample of freshmen in a northwestern Nigeria monotechnic. Int J Med Res Health Sci [accepted].

20. Mcmurray HR, Nguyen D, Westbrook TF, Mcance DJ. Biology of human papillomaviruses. Int J Exp Pathol 2001; 82: 15-33.

21. La Vecchia C, Franceschi S, Decarli A, et al. Sexual factors, venereal diseases, and the risk of intraepithelial and invasive cervical neoplasia. Cancer 1986; 58: 935-41.

22. Markowitz LE, Dunne EF, Saraiya M, et al. Quadrivalent human papillomavirus vaccine: recommendations of the Advisory Committee on Vaccination Practices (ACIP). MMWR Recomm Rep 2007; 56: 1-24.

23. Centers for Disease Control and Prevention. Genital HPV infection - Fact sheet. Accessed on January 22, 2020. URL: https://www. cdc.gov/std/hpv/stdfact-hpv.htm

24. Gravitt PE, Winer RL. Natural history of HPV infection across the lifespan: Role of viral latency. Vaccines 2017; 9: E267.

25. Morounke SG, Ayorinde JB, Benedict AO, et al. Epidemiology and incidence of common cancers in Nigeria. J Cancer Biol Res 2017; 5: 1105.

26. Bisi-Onyemaechi AI, Chikani UN, Nduagubam O. Reducing incidence of cervical cancer: knowledge and attitudes of caregivers in Nigerian city to human papilloma virus vaccination. Infect Agent Cancer 2018; 13: 29. 